\title{
ICE AND WHITE ROSES
}

\section{A distant memory.}

\section{BY REBECCA BIRCH}

“I always preferred white roses," Maria said, sliding an arthritis-clawed finger over a velvety red petal. The diamond in her wedding ring caught a sunbeam, casting a fractured rainbow onto the smooth face of the young woman sitting in the chair facing her. The woman's expression was guarded, her hands clenched in her lap. She perched on the front edge of the chintzcovered chair as if she were preparing to bolt.

The rainbow slid across her turned-down lips.

Maria sighed and set the bouquet of red roses on her side table next to the digitally timed pillbox. "It's kind of you to bring them."

The young woman leaned back a bit. "Mum said that you liked roses."

"Oh?" Maria asked, brightening. "Who is your mother? Do I know her?"

A frown furrowed the young woman's brow. "My mother was Sigrid Jonsson. Your daughter."

Maria blinked. Where was Sigrid? She'd last seen her ... digging worms in the back garden. It had been a long time since Maria had checked on her and the child didn't always remember to stay out of the green beans and lettuce. "Will you excuse me?" she asked, reaching for her cane. "I need to be sure Sigrid's not uprooting the vegetables."

The young woman touched the back of Maria's hand. "Wait," she said. "I just came in. Everything was fine outside. Nana, please." She swallowed and her fingers pressed just a bit harder. "We need to talk."

A sharp constriction pulled at Maria's chest. Her eyes flashed to the cryopreserver on the mantel, displaying her wedding bouquet of white roses. "Is it about Harry? Has there been word?"

She never should have agreed to let him go. Just a brief exploratory mission, he'd said. I'll be back before you know it. The white roses had barely begun to crystallize. She hadn't even known she was pregnant when he left.

"No, Nana," the woman said. "There's been no word. It's about what we talked about the last time I was here."

She'd been here before? Maria squinted, looking for any familiarity in the soft

$\rightarrow$ NATURE.COM Follow Futures: @ @NatureFutures $f$ go.nature.com/mtoodm face framed by pale curls. "I'm sorry, dear, but I seem to have forgotten your name?"
The woman squeezed the bridge of her nose and blinked away a bright sheen in her eyes. "I'm Margaret, Nana, and I need you to try to focus."

Focus. That was how the government

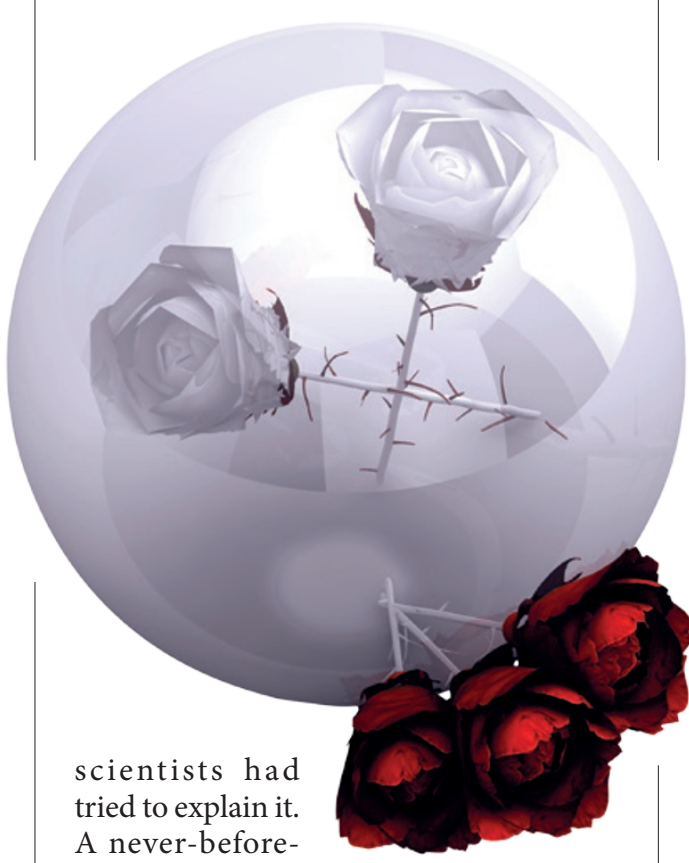

A never-before-

observed phenom-

enon in the vast nothingness between the orbits of Jupiter and Saturn, funnelling the faint rays of the Sun into a vortex. Not a black hole. Inexplicable. Harry's ship, the Kennedy, had reported launching exploratory probes, then had never been heard from again.

But he'd be back. He'd sworn it by the ice-crusted roses waiting to be thawed and spread over their graves when they both had passed beyond. His homing beacon, he'd called it. His lodestone.

"Do you remember what we talked about?"

Maria blinked away the blur of tears that had formed in her eyes and tried to concentrate. This nice young woman had brought her flowers. She owed her the courtesy of trying. The light touch on the back of her hand felt familiar. Conjured a wisp of memory. The same low voice. The words...

"You want me to come with you," Maria breathed. "Somewhere far from here."

"Yes. Good. That's right."

Maria opened her eyes. "I'm not leaving."

"I know you feel comfortable here, Nana," the young woman said, tucking a curl behind one ear with her free hand, "but I've been offered a position at the Mars habitat ring. It's what I've wanted all my life. I'll be involved in research I couldn't even consider here on Earth."

Maria shook her head, chewing on her lower lip.

“There are good facilities there. They'll be able to take excellent care of you --"

"No," Maria said. "Sigrid is happy here. And when Harry returns, this is where he'll look for me."

"Mars is closer to the anomaly," the young woman said, leaning close. Her breath smelled of cinnamon, the sharp scent overwhelming the soft odour of the roses. "If that's where grandfa - Harry - is, you'll be closer to him."

"I've told you, I'm not leaving. Now please, Sigrid will be in soon and she'll be wanting her lunch." Maria turned her body pointedly away.

The woman sighed, then gathered up her handbag and rose to her feet. "I wish you'd come of your own volition, Nana, but you need to know that the courts have named me your legal guardian. You'll be coming with me..."

Maria gazed at the decorative cryopreserver, and the woman's voice faded into a low drone at the edge of her awareness. From the surface of the curved glass, she saw Harry's eyes gazing out at her, as they had since the moment the Kennedy lost contact. They looked different from what she remembered. When had those wrinkles appeared around the edges? Why did he look so sad?

The door closed behind the young woman with a muted thud.

Groaning, Maria struggled to her feet, leaning heavily on her cane, and crossed to the mantel. She touched the curved glass, just above her husband's brow. "Hurry home, my love," she whispered. "Sigrid and I will be waiting."

Moisture glimmered in the corner of his eye. His lashes touched the skin of her palm, whisper-soft.

The pillbox chimed and Maria turned away. The room smelled of roses and cinnamon. She swallowed her pills, then touched the bouquet beside the box, wondering where it had come from.

"I always preferred white roses," she said. .

Rebecca Birch is a Seattle resident who has been published in markets including Nature, Grantville Gazette's Universe Annex and Penumbra eMag. You can find her online at www.wordsofbirch.com. 